\title{
Regional studies of fluid inclusions in Paleozoic sediments from southern Scandinavia
}

\author{
JØRGEN JENSENIUS
}

\begin{abstract}
Jensenius, J.: Regional studies of fluid inclusions in Paleozoic sediments from southern Scandinavia. Bull. geol. Soc. Denmark, vol. 36, pp. 221-235, Copenhagen, December, 31st, 1987. https:// doi.org/10.37570/bgsd-1988-36-04
\end{abstract}

\begin{abstract}
Fluid inclusions in diagenetic quartz and calcite have been investigated in order to determine minimum temperatures attained during diagenesis and obtain information on composition of porewaters in the Paleozoic sediments. Surface samples from Bornholm, Skåne and Gotland and drill core samples from Frederikshavn 1, Rønde 1, Nøvling 1, Åbenrå 1, Slagelse 1 and $\emptyset$ rslev 1 have been studied. Two major types of fluids are described: aqueous and hydrocarbon mixtures. The aqueous inclusions can roughly be divided into 3 different groups based on homogenisation temperatures with arithmetic means of $82^{\circ} \mathrm{C}$ (with a salinity around 25 eq. wt. \% salts) and $136^{\circ}$ and $175^{\circ} \mathrm{C}$ (with salinities around 5 eq. wt. \% salts). The correlation of temperatures and salinities of porewater is tentatively explained by dehydration of clay minerals diluting the porewaters. The hydrocarbon inclusions, some of which fluoresce green-yellow, homogenize into the liquid phase at temperatures between $-44^{\circ}$ to $+138^{\circ} \mathrm{C}$, and are only found in calcite veins from the Silurian of Nøvling 1 and the Lower Ordovician Komstad limestone, Bornholm. With regard to the thermal history the data indicate that 1: major thermal maturation occurred in pre-Carboniferious times 2: all Cambro-Ordovician samples are post-mature with respect to hydrocarbon generation and 3: only small, dry gas potentials are present in the upper Silurian to Carbonifereous rocks.
\end{abstract}

Jørgen Jensenius, Institute for Petrology, University of Copenhagen, Østervoldgade 10, DK-1350 Copenhagen $K$, Denmark.

\section{Introduction}

Fluid inclusions in syntaxial quartz overgrowths, mineral cement infilling intergrain voids and fracture infilling minerals represent samples of the fluids which at different times percolated through a sedimentary pile. Thus fluid inclusion studies potentially provide information on diagenetic conditions, such as temperatures of quartz diagenesis (Pagel 1975, Haszeldine et al. 1984a), timing of hydrocarbon migration (Burruss et al. 1983,1985 ), the behaviour of porewater (Haszeldine et al 1984b, Jensenius 1987), compositional changes of hydrocarbon phases (Horsfield and McLimans 1984) and on dissolved salts in porewater during progressive diagenesis. However, it should be emphasized that the fluid inclusions do not reveal the complete evolutionary history of the porewaters but only those periods when fluid entrapment occurred. Furthermore, temperatures obtained by fluid inclusion studies normally represent the precipitation temperatures of the host mineral and not integrals of time and temperature as do studies of vitrinite reflectance, conodont alteration indices etc. (Waples 1980). Therefore, fluid inclusions may re- cord the temperature of very short thermal events unlike the other methods mentioned. As we can not be sure that the obtained temperatures represent the maximum temperatures attained during the diagenetic history, they must be viewed as minimum temperatures.

Previous fluid inclusion studies on Danish sedimentary material are few. Fabricius $(1984,1985)$ studied fluid inclusions in quartz crystals and halite from salt diapirs, and Sønderholm and Fabricius (1983), Jensenius (1987) and Jensenius et al. (in prep) studied fluid inclusions in calcite veins from the Cretaceous of the Danish Central Graben. The purpose of the present study is to use fluid inclusions to estimate temperatures and pressures (depths) attained during diagenesis of Lower Paleozoic Danish sediments and to obtain information on the composition of the porewaters during diagenesis.

\section{Location and nature of material studied}

Nineteen samples of Paleozoic and Precambrian rocks from Danish drill cores and surface local- 
Table 1. Sample list with locations for surface samples and depth, box and core no. for well samples. Age/formation/description of sample types and type of inclusion host are given. Skelbro 1 and Billegrav 1 are shallow borings from Bornholm.

\begin{tabular}{|c|c|c|c|c|c|}
\hline $\begin{array}{l}\text { Drill cores } \\
\text { Sample } \\
\text { no. }\end{array}$ & $\begin{array}{l}\text { Boring } \\
\text { location }\end{array}$ & Core/box & $\begin{array}{l}\text { Approx. } \\
\text { depth }\end{array}$ & $\begin{array}{l}\text { Formation/age/ } \\
\text { description }\end{array}$ & $\begin{array}{l}\text { Inclusion } \\
\text { host }\end{array}$ \\
\hline $\begin{array}{l}\text { EFP-1 } \\
\text { EFP-2 } \\
\text { EFP-3 } \\
\text { EFP-17 } \\
\text { EFP-19 } \\
\text { EFP-20 } \\
\text { EFP-21 } \\
\text { EFP-24 } \\
\text { EFP-27 } \\
\text { EFP-28 } \\
\text { EFP-31 } \\
\text { EFP-42 } \\
\text { EFP-46 }\end{array}$ & $\begin{array}{l}\text { Skelbro 1 } \\
\text { Skelbro } 1 \\
\text { Skelbro 1 } \\
\text { Frederikshavn } 1 \\
\text { Nøvling 1 } \\
\text { Nøvling } 1 \\
\text { Nøvling } 1 \\
\text { Rønde 1 } \\
\text { Slagelse } 1 \\
\text { Slagelse 1 } \\
\text { Billegrav 1 } \\
\text { Åbenrå } 1 \\
\text { Orslev 1 }\end{array}$ & $\begin{array}{c}190 / 1 \\
2 / 26 \\
2 / 20 \\
3 / 10 \\
1 / 18 \\
7 / 1 \\
16 / 1 \\
\\
27-31 / 13 \\
1 / 19\end{array}$ & $\begin{array}{c}40.1 \mathrm{~m} \\
3.3 \mathrm{~m} \\
2.8 \mathrm{~m} \\
1312 \mathrm{~m} \\
3554 \mathrm{~m} \\
3547 \mathrm{~m} \\
3632 \mathrm{~m} \\
5241 \mathrm{~m} \\
2640 \mathrm{~m} \\
2973 \mathrm{~m} \\
5.7 \mathrm{~m} \\
2298 \mathrm{~m} \\
2101 \mathrm{~m}\end{array}$ & $\begin{array}{l}\text { Rispebjerg sst. } \\
\text { Komstad limestone } \\
\text { Komstad limestone } \\
\text { Precambrian metasst. } \\
\text { U. Ludlowian siltst. } \\
\text { U. Ludlowian siltst. } \\
\text { U. Ludlowian siltst. } \\
\text { L. Ludlowian siltst. } \\
\text { Silurian siltst. } \\
\text { Hardeberga sst. } \\
\text { Alum shale } \\
\text { Ordovician shale } \\
\text { Carboniferous clayst. }\end{array}$ & $\begin{array}{l}\text { quartz cement } \\
\text { vein calcite } \\
\text { vein calcite } \\
\text { vein quartz } \\
\text { vein calcite } \\
\text { vein calcite } \\
\text { vein calcite } \\
\text { vein calcite } \\
\text { vein quartz } \\
\text { quartz cement } \\
\text { vein calcite } \\
\text { vein quartz } \\
\text { vein calcite }\end{array}$ \\
\hline $\begin{array}{l}\text { Surfaces samples } \\
\text { Sample } \\
\text { no. }\end{array}$ & Location & & & Formation & $\begin{array}{l}\text { Inclusion } \\
\text { host }\end{array}$ \\
\hline $\begin{array}{l}\text { EFP-6 } \\
\text { EFP-7 } \\
\text { EFP-8 } \\
\text { EFP-9 } \\
\text { EFP-53 } \\
\text { EFP-54 }\end{array}$ & $\begin{array}{l}\text { Balka sstq., Borr } \\
\text { Pedersker sstq., } \\
\text { Slusegård, Bornh } \\
\text { Borggård, Bornh } \\
\text { Komstad, Skåne } \\
\text { Lilla Snogrinde } 4\end{array}$ & & & $\begin{array}{l}\text { Hardeberga sst. } \\
\text { Hardeberga sst. } \\
\text { Cyrtograptus shale } \\
\text { Exulans limestone } \\
\text { Komstad limestone } \\
\text { Klinteberg limestone }\end{array}$ & $\begin{array}{l}\text { vein quartz } \\
\text { quartz cement } \\
\text { vein calcite } \\
\text { vein calcite } \\
\text { vein calcite } \\
\text { vein calcite }\end{array}$ \\
\hline
\end{tabular}

sst. sandstone, sstq. sandstone quarry, siltst. siltstone, calyst. claystone, metasst. metamorphosed sandstone.

ities from Bornholm, Skåne and Gotland (Table 1) have been examined. The locations of borings and surface samples are shown in fig. 1 , and the chronostratigraphy in fig. 2 together with the stratigraphic level of the examined samples. The sandstones range in composition from quartzites to arkoses. They are commonly cut by late calcite and quartz veins, which postdate the quartz overgrowths and the compaction. Also in the shales the veins clearly are very late post compactional features. Thomsen et al. (1983) describes the mineralogy of the Paleozoic rocks and shows that muscovite, mica and chlorite are the dominating layer minerals in lower Paleozoic rocks, whereas mica, chlorite, kaolinite, and mixed-layer micasmectite are found in the upper Paleozoic rocks.

\section{Analytical methods}

Microthermometry analyses were performed with a Chaixmeca cooling and heating stage (Poty et al 1976), calibrated against compounds (Jehl 1975) of known melting point. All temperatures given have been corrected with the obtained calibration curve and are considered accurate to $+/$ $1^{\circ} \mathrm{C}$ in the temperature range reported; (this gives an accuracy of the salinities of 1.8 and $0.4 \mathrm{wt}$. \% for estimated salinities of 5 and 25 equivalent wt. $\% \mathrm{CaCl}_{2}$, respectively). The low accuracy is mainly caused by low repoducibility in the melt-

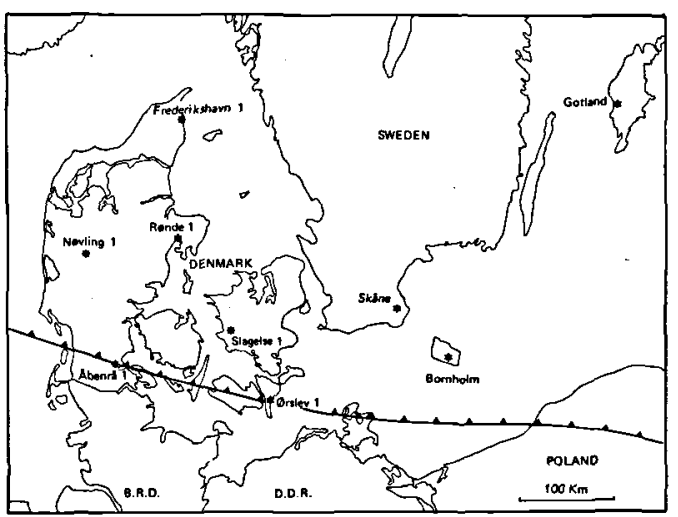

Fig. 1. Location of borings and surface sites sampled. The Caledonian deformation front is shown (modified from Ziegler 1978). The major sedimentation during Lower Paleozoic occurred North and East of this. List of examined samples is given in table 1. 


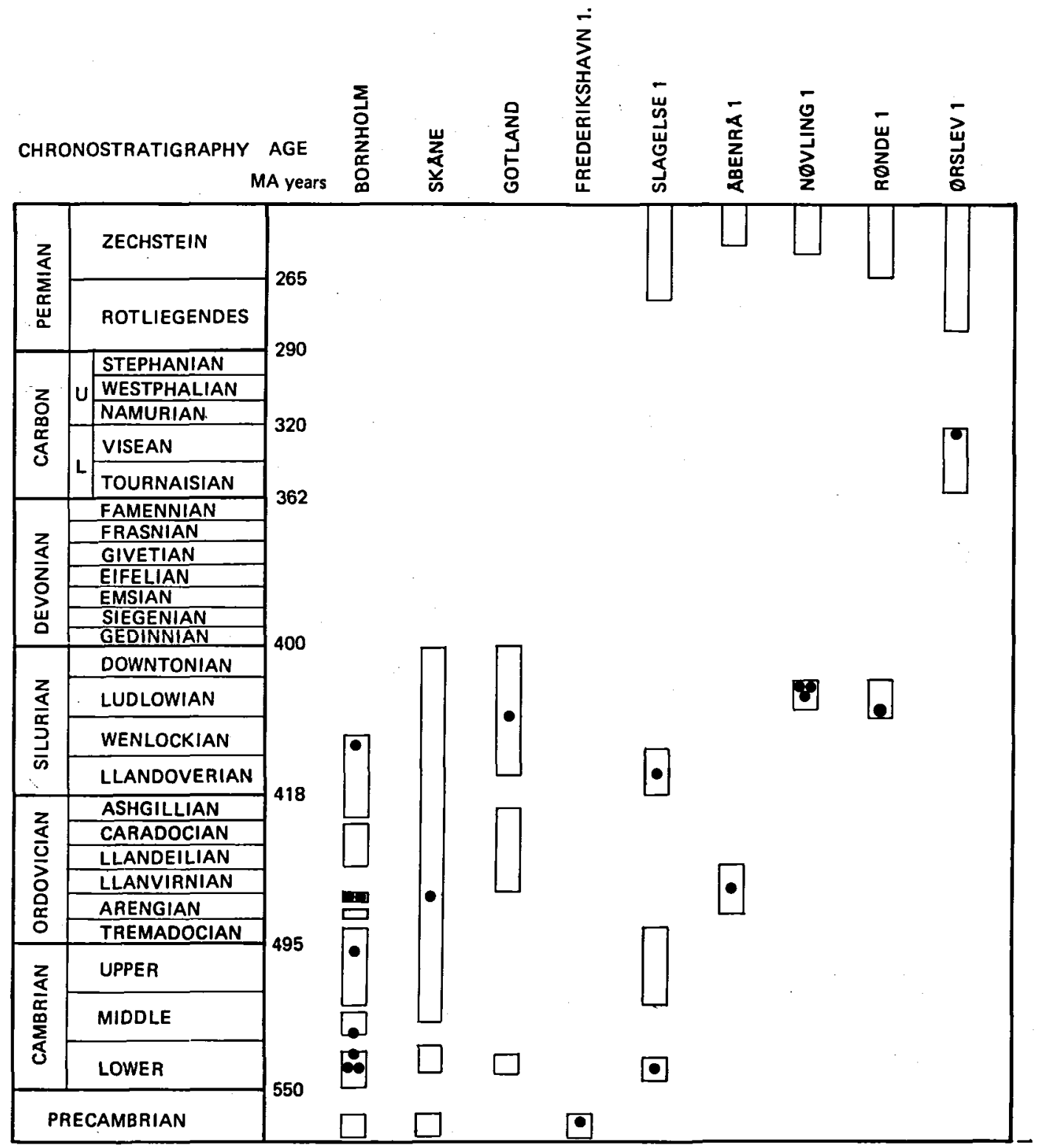

Fig. 2. Chronostratigraphy of examined samples indicated by dots. Diagram based on data from Magnusson et al (1963), Christensen (1971), Rasmussen et al (1971, 1973), Poulsen (1974), Surlyk (1980), Bergstrøm et al (1982), Odin (1982) and Frykman (pers. com. 1985 , on the geology of Gotland).

ing of the standard compounds. The reproducibility on fluid inclusions homogenisation temperatures is $+1-0.2^{\circ} \mathrm{C}$.

Fluoroscence microscopy (FM) was performed with violet-blue light induced fluorescence (390$490 \mathrm{~nm})$.

Cathodoluminiscence microscopy (CLM) conditions were attained at $12 \mathrm{KV}, 5-7 \mathrm{~mA}$, focussed beam, at a vacuum of $40-50 \mathrm{mTor}$. CLM was performed on a Luminoscope, model ELM2B, from Nuclide Corp.

\section{Types of fluid inclusions}

Fluid inclusions in both fracture filling quartz and calcite, and syntaxial quartz overgrowing detrital quartz grains have been examined. The following 

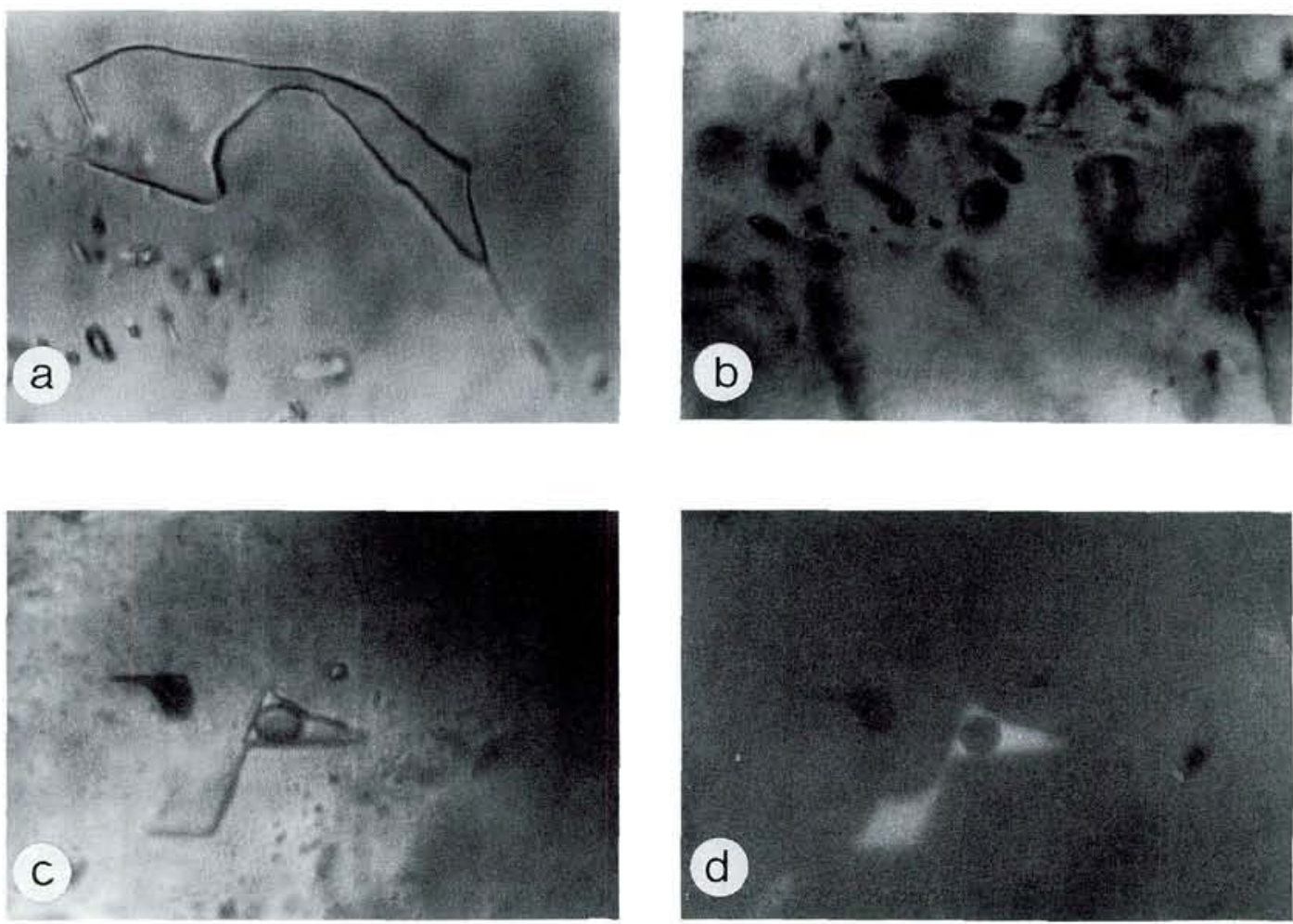

Fig. 3. Examples of fluid inclusion types observed in calcite from veins in Nøvling 1. A: One phase liquid aqueous inclusion (EFP-20). Width of field $1000 \mu \mathrm{m}$. B: Two-phase liquid-gas hydrocarbon inclusion within a healed fracture (EFP-21). Width of field $100 \mu \mathrm{m}$. C: Two- phase liquid-gas hydrocarbon inclusion (EFP-21). Normal light. Width of field $65 \mu \mathrm{m}$. D: As C but under fluorescence microscope. The liquid hydrocarbon phase fluoresce green-yellow.

types of inclusions may be distinguished by their phase relations at room temperature.

Type Aq(1): Aqueous 1-phase liquid inclusions (fig. 3 a) which may nucleate a vapour bubble on cooling.

Type $\mathrm{Aq}(2)$ : Aqueous 2-phase liquid-vapour inclusions. By far the most abundant type in most examined samples. Traces of gases such as hydrocarbons may be present in the vapour phase of some of these inclusions.

Type HC(1 or 2): 1-phase liquid and 2-phase liquid-gas hydrocarbon inclusions, some of which show fluorescence (fig. 3 B,C,D).

Type $\mathrm{CM}(1)$ : 1-phase $\mathrm{CO}_{2}-\mathrm{CH}_{4}$ inclusions, which are very rare.

The inclusions occur both isolated and along healed fracture planes. Occasionally fluid inclusions were observed along "dust rims" outlining the contact between detrital quartz grain and the quartz overgrowth (cement). The size of the inclusions varies from a few to about $100 \mu \mathrm{m}$ but are generally around $10 \mu \mathrm{m}$. Their shape varies from very irregular to well rounded.

A description of the types of fluid inclusions in

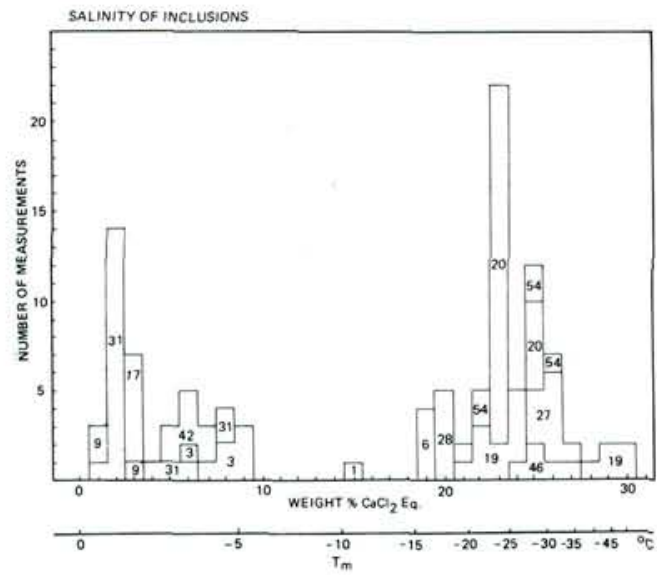

Fig. 4. Final melting temperatures of ice in aqueous liquidvapour inclusions and the corresponding salinities, given as equivalent weight $\% \mathrm{CaCl}_{2}$ Sample numbers are indicated in the columns (EFP-X). 
Table 2. Salinities, final melting temperature of ice and initial melting temperatures for ice in aqueous inclusions.

\begin{tabular}{lccc}
\hline $\begin{array}{l}\text { Sample } \\
\text { no. }\end{array}$ & $\begin{array}{c}\text { Initial } \\
\text { melting }\end{array}$ & $\begin{array}{c}\text { Final } \\
\text { melting }\end{array}$ & $\begin{array}{c}\text { Salinity } \\
\text { eq. wt } \% \mathrm{CaCl}_{2}\end{array}$ \\
\hline EFP-19+20 & $-65^{\circ}--53^{\circ} \mathrm{C}$ & $-47.2^{\circ}--19.9^{\circ} \mathrm{C}$ & $21.3-29.8 \%$ \\
EFP-27 & $-58^{\circ} \mathrm{C}$ & $-32.9^{\circ}--27.0^{\circ} \mathrm{C}$ & $24.5-26.6 \%$ \\
EFP-6 & $-57^{\circ}--45^{\circ} \mathrm{C}$ & $-19.5^{\circ}--15.2^{\circ} \mathrm{C}$ & $18.5-20.9 \%$ \\
EFP-54 & $-49^{\circ}--42^{\circ} \mathrm{C}$ & $-28.7^{\circ}--21.8^{\circ} \mathrm{C}$ & $22.3-25.4 \%$ \\
EFP-33 & $-33^{\circ}--32^{\circ} \mathrm{C}$ & $-4.7^{\circ}--0.7^{\circ} \mathrm{C}$ & $1.4-8.2 \%$ \\
\hline
\end{tabular}

the individual samples examined is given in the appendix together with a short description of samples.

\section{Results of microthermometry}

Aqueous inclusions

Temperatures of homogenization (into the liquid phase) and final melting of ice (with the corresponding salinities) of aqueous liquid-vapour inclusions in the examined samples are shown in figures 4 through 7 . The results are briefly commented on below.

Salinities (fig. 4), as inferred from the temperature of final melting of ice, have been expressed in terms of equivalent weight $\% \mathrm{CaCl}_{2}$ instead of the normally used eq. wt. \% $\mathrm{NaCl}$ because of the very low temperatures of first melting and the low final melting of ice in a number of the aqueous inclusions (Table 2 and fig. 4). In the $\mathrm{NaCl}-\mathrm{H}_{2} \mathrm{O}$ system eutectic melting occurs at $-21.2^{\circ} \mathrm{C}$ and in the system $\mathrm{CaCl}_{2}-\mathrm{H}_{2} \mathrm{O}$ at $-49.8^{\circ} \mathrm{C}$ (Linke 1958). Hence it is considered more pertinent to express the observed melting point depressions in terms of eq. wt. $\% \mathrm{CaCl}_{2}$. This change in convention does not introduce any large difference in salinities.

Salinities vary between 0.7 and 29.8 equivalent weight $\% \mathrm{CaCl}_{2}$ although the range obtained in individual samples is significantly smaller (fig. 4). A well defined bimodal distribution of salinities around $5 \%$ and $25 \%$ is apparent and these are referred to later as the low and high salinity groups of inclusions.

Inclusions in calcite veins from Bornholm all belong to the low salinity group, whereas inclusions in calcite veins from Nøvling 1 , Ørslev 1 , Skåne and Gotland belong to the high salinity group (fig. 4). The highest salinities were obtained in the calcite veins of Nøvling 1. Final melting temperatures for these inclusions were close to the eutectic of the system $\mathrm{CaCl}_{2}-\mathrm{H}_{2} \mathrm{O}$ (Table 2). In a few of these inclusions minute crystals were observed, either as discrete crystals in the liquid phase or, as in one inclusion, apparently attached radially to the vapour bubble. These crystals melted at $-21.6^{\circ},-1.7^{\circ}$ and $+0.7^{\circ} \mathrm{C}$ and probably signify the presence of the $\mathrm{CaCl}_{2} \cdot 6 \mathrm{H}_{2} \mathrm{O}$ hydrate (Crawford 1981, Linke 1958).

No difference in salinity between fluid inclusions in quartz and calcite veins could be found.

Temperatures of Homogenization $\left(T_{h}\right)$ vary between $36^{\circ}$ and $361^{\circ} \mathrm{C}$ (fig. 5) but generally cluster in 3 groups around the arithmetric averages $82^{\circ}$ (range: $50-100^{\circ} \mathrm{C}$ ) $136^{\circ}$ (range: $100-170^{\circ} \mathrm{C}$ ) and $175^{\circ} \mathrm{C}$ (range: $150-200^{\circ}$ ) depending on the sample location and the stratigraphic position (fig. 7). Homogenization always occurred into the liquid phase.

Calcite veins from Bornholm all belong to the $136^{\circ} \mathrm{C}$ group, whereas the calcite veins from $\mathrm{N} ø \mathrm{v}$ ling $1, \varnothing$ rslev 1 , Skåne 1 and Gotland all belong to the $82^{\circ} \mathrm{C}$ group (fig. 6). Inclusions in the quartz veins from Bornholm and Slagelse 1 similarly belong to the $82^{\circ} \mathrm{C}$ group (fig. 6) whereas inclusions in the quartz veins from Åbenrå 1 form the $175^{\circ} \mathrm{C}$ group. The inclusions from the quartz veins from Frederikshavn 1 give two different groups of homogenization temperatures in different healed fractures: one around $180^{\circ} \mathrm{C}$ and a second around $345^{\circ} \mathrm{C}$ (fig. 5). Inclusions from quartz overgrowths in sandstones in some cases belong to the $136^{\circ} \mathrm{C}$ group (the Hardeberga sandstone of Bornholm and Slagelse 1), whereas other inclusions homogenize at much higher temperatures (the Rispebjerg sandstone of Bornholm) (fig. 6).

Salinity versus temperature of homogenization. is shown in fig. 8. Generally inclusions with high salinities homogenize below $100^{\circ} \mathrm{C}$, whereas inclusions with low salinities homogenize in the range $110-190^{\circ} \mathrm{C}$. The only inclusions which do not conform to this grouping are from the Hardeberga sandstone of Slagelse 1 .

Clathrate (gas hydrate) formation was observed in a few aqueous liquid-vapour inclusions from a quartz vein from the Hardeberga sandstone (Bornholm). Its presence was identified by a ragged meniscus between the aqueous liquid and vapour phase after final melting of ice had 

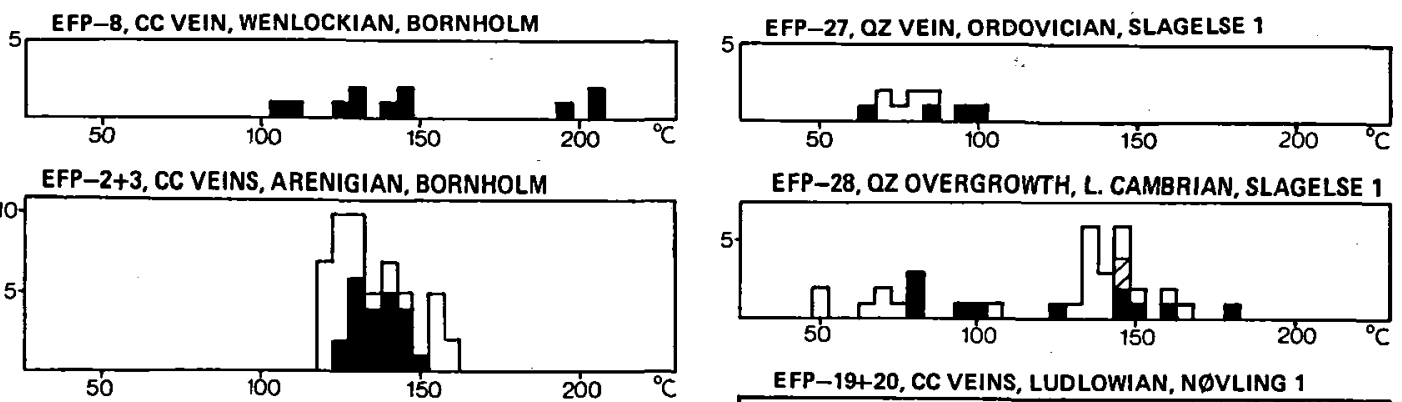

EFP-31, CC VEIN, U. CAMBRIAN, BORNHOLM

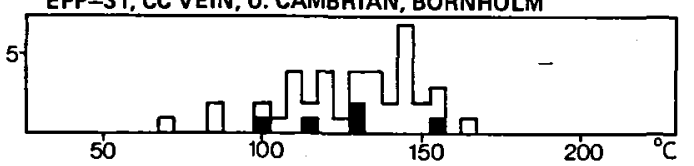

EFP-9, CC VEIN, M. CAMBRIAN, BORNHOLM

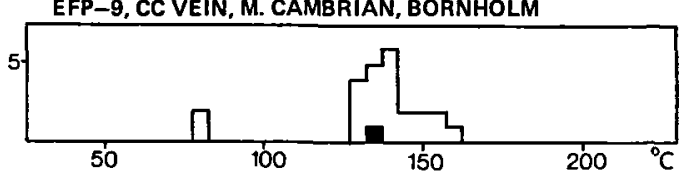

EFP-19+20, CC VEINS, LUDLOWIAN, NØVLING 1
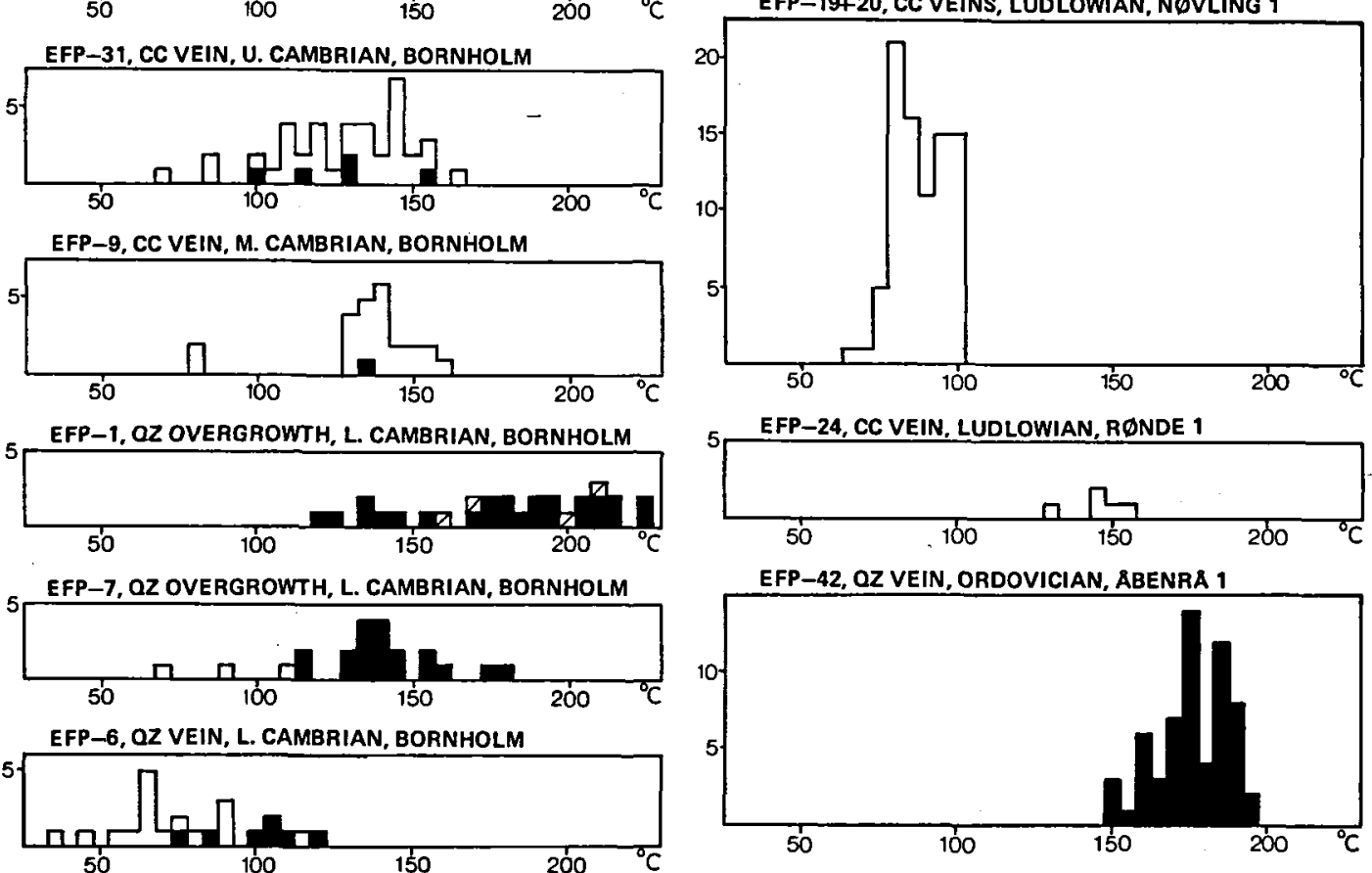

EFP-53, CC VEIN, ARENIGIAN, SKANE

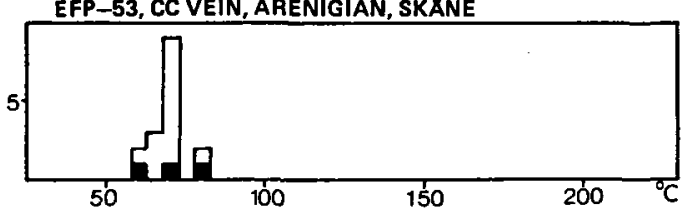

EFP-46, CC VEIN, CARBONIFEROUS, ØRSLEV 1
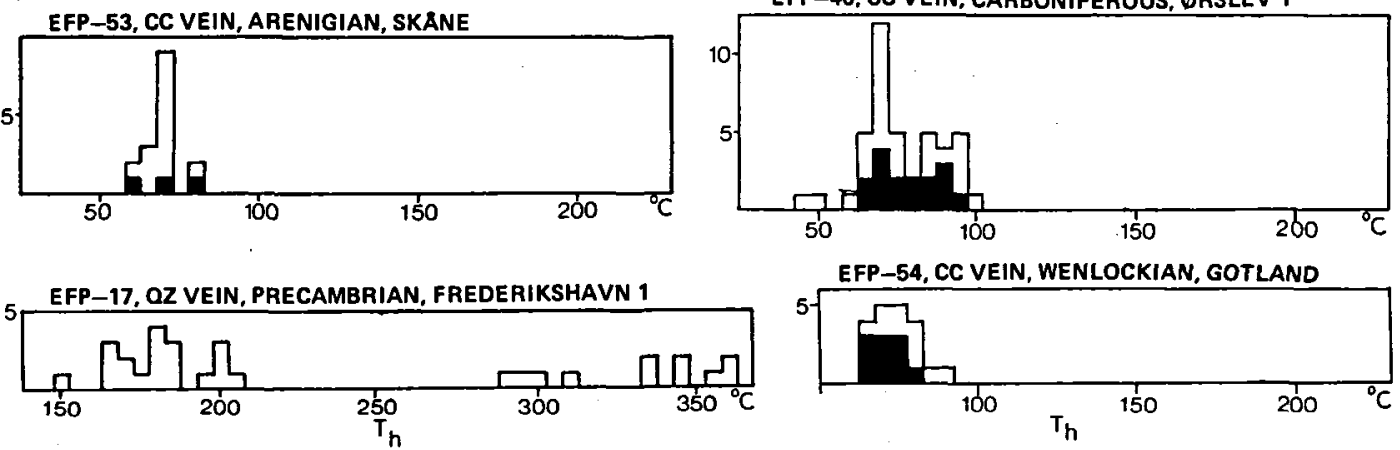

Fig. 5. Homogenization temperatures for aqueous inclusions. Filled and stippled columns denote isolated inclusions and inclusions found in "dust rims", respectively. Inclusions along healed fractures shown by blank.

occurred. Melting of the clathrate occurred at $+16^{\circ} \mathrm{C}$ (one measurement). This temperature strongly suggests the presence of traces of $\mathrm{CH}_{4}$ (or $\mathrm{H}_{2} \mathrm{~S}$ ) in the vapour phase, though in concen- trations too small to form a separate phase during cooling runs.

A group of two-phase aqueous inclusions located along a healed fracture in a quartz over- 

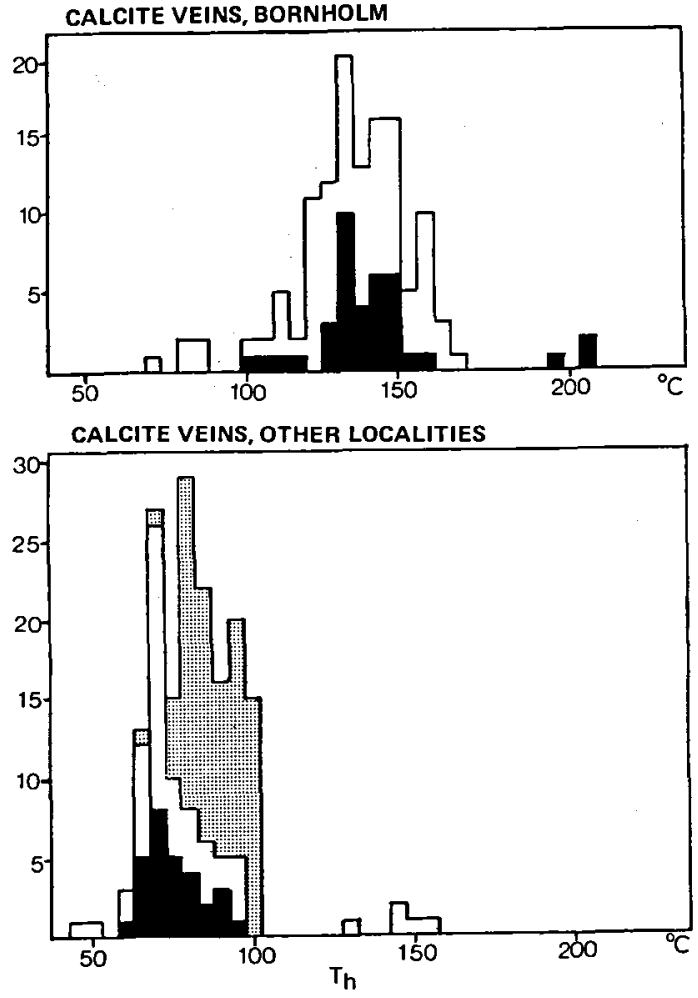

QUARTZ VEIN, SLAGELSE 1

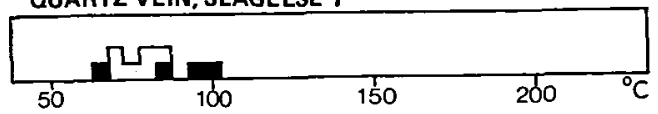

QUARTZ VEIN, BORNHOLM

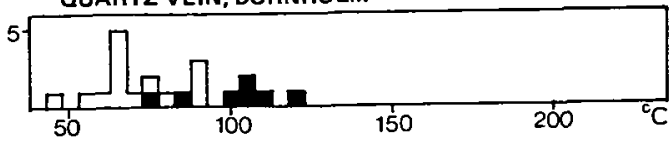

QUARTZ OVERGROWTH, BORNHOLM

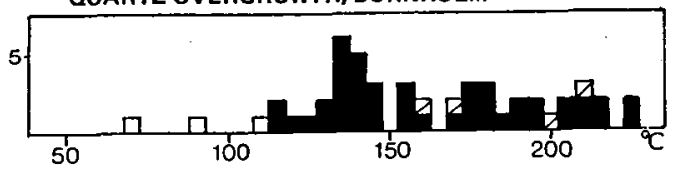

QUARTZ OVERGROWTH, SLAGELSE 1

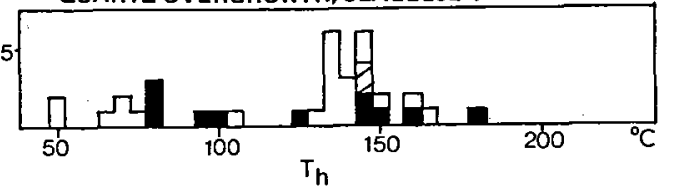

Fig. 6. Summary of homogenization temperatures for aqueous inclusions in calcite veins from Bornholm and other localities, plus quartz veins and quartz overgrowths from Bornholm and Slagelse 1.

growth from the Hardeberga sandstone in Slagelse 1 decrepitated before homogenization when healed to approximately $50^{\circ} \mathrm{C}$. This behaviour may also indicate the presence of gases such as methane in solution, as the presence of methane in solution may cause an internal pressure of up to $0.5 \mathrm{~Kb}$ to build up in the inclusion upon heating (Hanor 1980), which could be followed by decrepitation. It may be argued that quartz hosted inclusions of the same size as these $(10$ $\mu \mathrm{m}$ ) first decrepitate at $1.2 \mathrm{~Kb}$ (Leyroy 1979), but as the described inclusions are found along a heated fracture they probably decrepitate at lower pressures. No clathrate formation was observed in these inclusions.

Hydrocarbon and gaseous inclusions in the calcite vein cutting the Komstad limestone (EFP-3) a group of isolated two and one-phase hydrocarbon inclusions was found. No solidification was achieved upon cooling to $-150^{\circ} \mathrm{C}$. Homogenization to liquid occurred between $-44.5^{\circ} \mathrm{C}$ and $+54^{\circ} \mathrm{C}$ (fig. 9). Some of these inclusions fluoresce

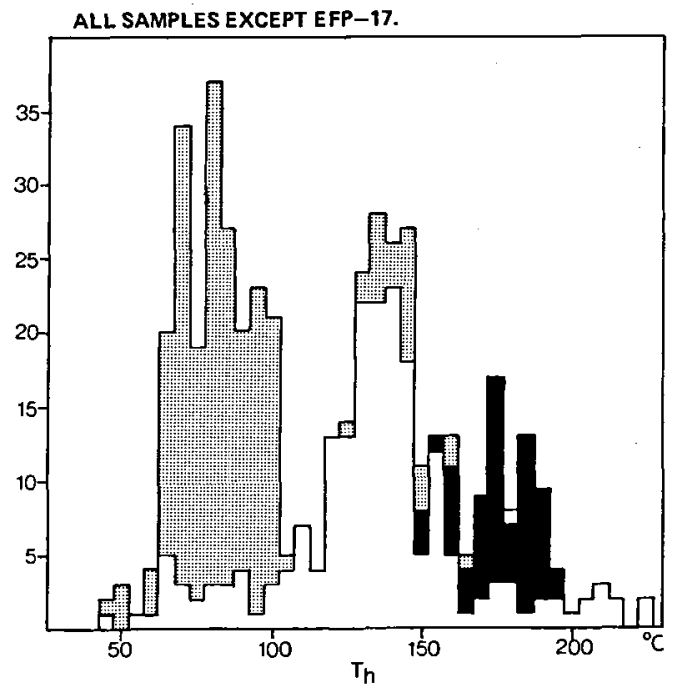

Fig. 7. Homogenization temperatures for aqueous inclusions from all samples, except EFP-17. Blank, filled and grey columns denotes samples from Bornholm, Åbenrå 1 and other localities, respectively. 
SALINITY VS. TEMPERATURE

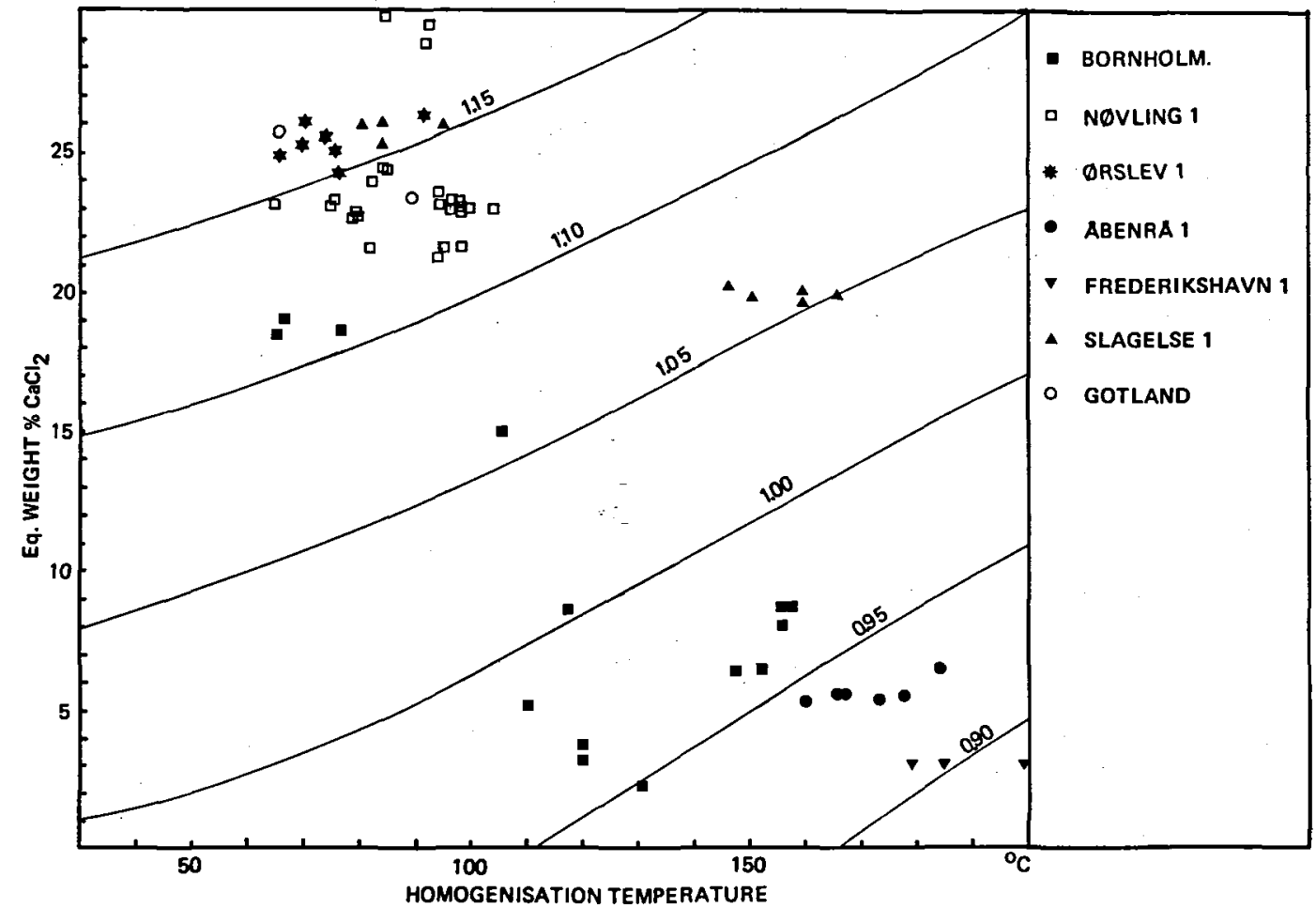

Fig. 8. Salinity versus homogenization temperatures for aqueous inclusions from the locations and borings identified on the diagram. Isodensity lines based on the diagram of Bodnar (1983) are shown.

green-yellow during UV fluorescence microscopy (see fig. 9).

In one calcite vein from Nøvling 1 (EFP-21) a group of two-phase hydrocarbon inclusions was found along healed fractures. Two inclusions homogenized to liquid as low as $+42.4^{\circ} \mathrm{C}$ and $+45.1^{\circ} \mathrm{C}$ whereas most homogenized around $131^{\circ} \mathrm{C}$ (fig. 9). None of these inclusions solidified when cooled to $-140^{\circ} \mathrm{C}$. They all fluoresce greenyellow (fig. 3) and are thus considered to be composed of hydrocarbons. The two inclusions homogenizing at low temperatures belong to a separate healed fracture.

In a calcite vein from Rønde 1 (EFP-24) a group of 8 fracture-bound, one-phase fluid inclusions nucleated a gas phase on cooling. The homogenization temperatures of these inclusions range between $-12.7^{\circ}$ and $+3.2^{\circ} \mathrm{C}$. In one inclusion melting of solid $\mathrm{CO}_{2}$ occurred at $-59.3^{\circ} \mathrm{C}$ and indicated the presence of other compounds such as methane or $\mathrm{N}_{2}$ in addition to $\mathrm{CO}_{2}$ (Burruss 1977, Touret 1982).

\section{Discussion}

Three compositional types of fluids can be distinguished in the examined material: 1) an aqueous solution with various amounts of dissolved salts, 2) an aqueous solution with dissolved salts

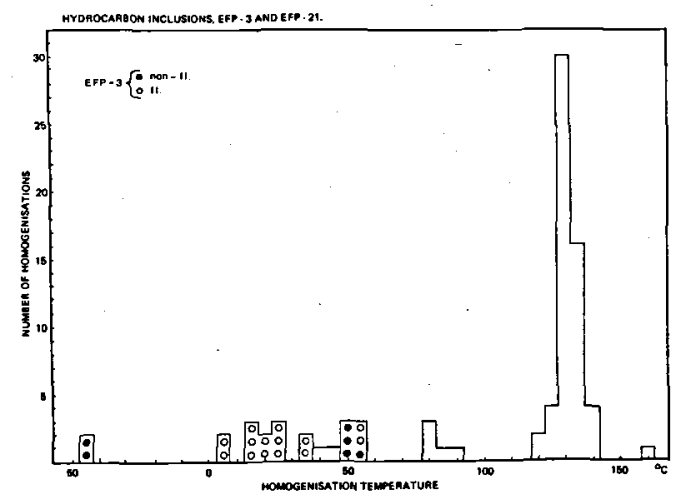

Fig. 9. Homogenizations temperatures of hydrocarbon inclusions from EFP-21 (blank) and EFP-3 (open and filled circles). In EFP-3 open and filled circles denote non-fluorescent and fluorescent inclusions, respectively. All inclusions from $\mathbf{N} \varnothing$ vling 1 are fluorescent. 


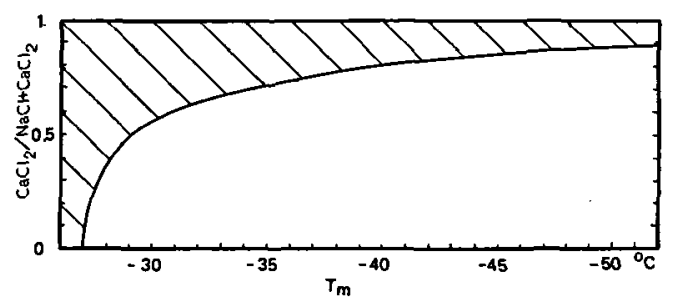

Fig. 10. Minimum $\mathrm{CaCl}_{2} / \mathrm{NaCl}+\mathrm{CaCl}_{2}$ ratios as a function of initial melting temperatures. The crosslined field shows possible compositions. Constructions based on data from J. Konnerup-Madsen (unpublished).

and traces of gases, and 3) hydrocarbon fluid mixtures. The first type is by far the most abundant and is found in fluid inclusions in both quartz overgrowth and in quartz and calcite veins. Types (2) and (3) are very rare and have only been found in 2 samples each. Hydrocarbon fluids were only found in inclusions from calcite veins, whereas aqueous fluids with traces of gases were found in both quartz overgrowths in sandstones and in quartz veins.

Chemical and physical characteristics of fluids. Salinities of the aqueous fluids vary between 0.7 and 29.8 weight \% salts, although most inclusions have salinities around 5 and 25 weight \% (fig. 4). Temperatures of homogenization vary widely, from $36^{\circ}$ to $361^{\circ} \mathrm{C}$, but with clusterings around $+80^{\circ},+135^{\circ}$ and $175^{\circ} \mathrm{C}$ (figs. 5 and 7 ), and densities between 0.88 and $1.19 \mathrm{~g} / \mathrm{cm}^{3}$ (fig. 8 ).

Salinities of aqueous fluids have been expressed in terms of equivalent weight $\% \mathrm{CaCl}_{2}$ because of the very low temperature of both first and final melting of ice (Linke 1958). However, microthermometry only provides information on the total concentration of salts in solution, not their identity and it may be anticipated that the entrapped fluids actually consist of a mixture of several salts such as $\mathrm{NaCl}, \mathrm{CaCl}_{2}$ and $\mathrm{MgCl}_{2}$ in solution. However, the very low first and final melting temperatures show that the solutions are rich in $\mathrm{CaCl}_{2}$ (and/or $\mathrm{MgCl}_{2}$ ). The very low temperature of first melting, below that of the eutectic in the $\mathrm{H}_{2} \mathrm{O}-\mathrm{NaCl}-\mathrm{CaCl}_{2}-\mathrm{MgCl}_{2}$ system at $-57^{\circ} \mathrm{C}$ (Crawford 1981), obtained in the calcite vein of $\mathrm{N} ø$ ling 1 (table 2) suggests that other salts must be present, such as $\mathrm{FeCl}_{3}$, or that metastable melting has occured.

An estimate of the relative amount of $\mathrm{CaCl}_{2}$ in solution can be made on the basis of the very low temperatures of final melting observed in some of the calcite veins, assuming the presence of only $\mathrm{NaCl}$ and $\mathrm{CaCl}_{2}$ in solution (fig. 10). Figure 10 shows the minimum $\mathrm{CaCl}_{2} \mathrm{NaCl}+\mathrm{CaCl}_{2}$ as a function of the final melting temperature, assuming metastable eutectic melting in the $\mathrm{H}_{2} \mathrm{O}-\mathrm{NaCl}$ $\mathrm{CaCl}_{2}$ system. Metastable melting is assumed due to the fact that $\mathrm{NaCl} \cdot \mathrm{H}_{2} \mathrm{O}$ does not normally not form in aqueous inclusions during cooling runs (Crawford, 1981). It can be seen that at least some of the samples contain fluids highly enriched in $\mathrm{CaCl}_{2}$. The presence of dolomite in the calcite veins from Nøvling 1 furthermore suggests that $\mathrm{MgCl}_{2}$ is present. As high salinities inhibit the precipitation of dolomite, either the $\mathrm{Mg}^{++} / \mathrm{Ca}^{++}$or $\mathrm{CO}_{3} / \mathrm{Ca}^{++}$ratio has to be high in order to overcome the kinetics of dolomite precipitation (Morrow 1984). The lack of $\mathrm{CO}_{2}$ fluid inclusions in the calcite vein favours the former possibility.

Low salinity fluids generally characterize limestones and shales of Middle Cambrian to Ordovician age, whereas higher salinities are found in Silurian and Carboniferous siltstones, the overgrowth in the Cambrian sandstone being an exception from this trend (fig. 8). No difference in salinities is apparent between fluids in quartz and calcite veins. This similarity suggests that the two vein types were probably formed during the same periods of the diagenetic history. This is in accordance with the observation that both are late diagenetic features.

Clathrate formation in some aqueous inclusions in the quartz vein from the Hardeberga sandstone (Bornholm EFP-6) and the decrepitation of aqueous inclusions in quartz overgrowths from the Hardeberga sandstone (Slagelse 1 EFP-28) indicate the presence of small amounts of gases such as methane in some of the inclusions.

The melting temperature of $\mathrm{CO}_{2}$ and the degree of filling at melting observed in the calcite of Rønde 1 can give information on the composition of the fluid phase. If it is assumed that methane and carbon dioxide are the only phases present, the diagrams of Swanenberg (1979) can be applied and reveal a composition of approximately 28 mole \% methane.

The isolated hydrocarbon inclusions found in the Komstad limestone of Bornholm (fig. 9) give a wide range in $T_{h}$. This suggests a wide range in 


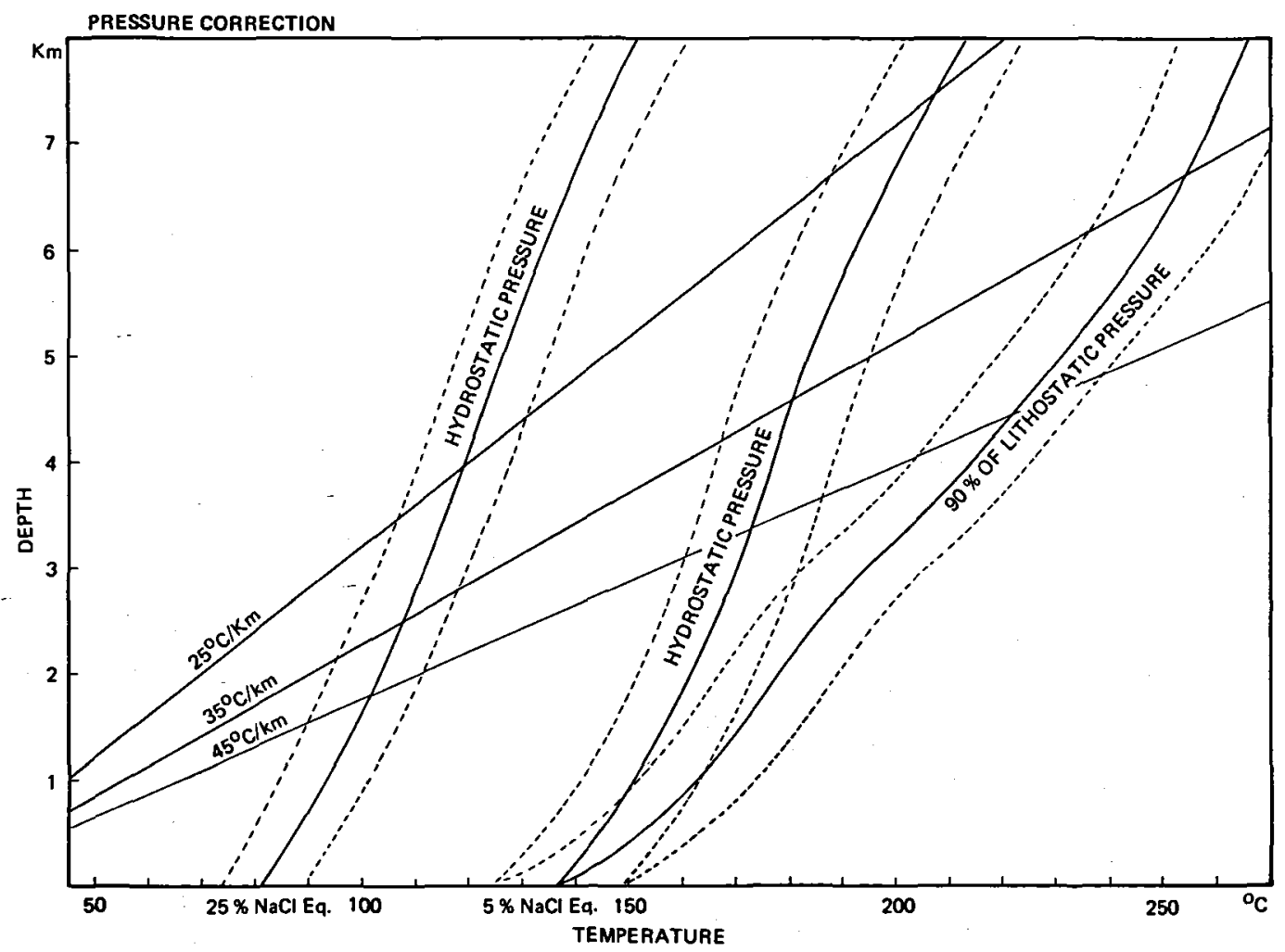

Fig. 11. Depth - temperature conditions for possible entrapment of two representive aqueous fluids $\left(5\right.$ wt. $\%$ salt, $\mathrm{T}_{\mathrm{b}}+82^{\circ} \mathrm{C}$; and 25 wt. $\%$ salt, $\mathbf{T}_{\mathbf{h}}+136^{\circ} \mathrm{C}$ ) for the depth - pressure conditions indicated on the diagram. For $136^{\circ} \mathrm{C}$ curve both hydrostatic and $90 \%$ of lithostatic pressure are applied (see discussion in text). Standard deviations are shown as broken lines. Average sediment density used is $2.3 \mathrm{~g} / \mathrm{cm}^{3}$. Also shown are 3 geothermal gradients. The pressure correction used is based on Potter (1977). See text for interpretation.

composition and/or density of the inclusions. The $T_{h}$ of these inclusions suggests that they are of a composition slightly more enriched in higher hydrocarbons than wet gas (typical wet gas: $85 \%$ $\mathrm{CH}_{4}, 6 \% \mathrm{C}_{2} \mathrm{H}_{6}, 5 \% \mathrm{C}_{3} \mathrm{H}_{10}, 4 \% \mathrm{HHC}$, Tiratsoo 1973). The presence of hydrocarbon gases in the vein inclusions is a possible explanation of the low $\delta^{13} \mathrm{C}$ values $(-21.8 \%$ and $-14.9 \%$ PDB $)$ found in some of the veins cutting the Komstad limestone by Buchardt and Nielsen (1985), as carbon originating from organic matter is depleted in ${ }^{13} \mathrm{C}$ (Carothers and Kharaka 1980, Jensenius et al. in prep.).

The well defined homogenization temperature peak (fig. 9) for hydrocarbon inclusions of the calcite veins cutting the Silurian limestones suggests a very homogeneous composition and constant entrapment conditions. The fluid is probably composed of a mixture of hydrocarbons dominated by hydrocarbons heavier than $\mathrm{C}_{3} \mathrm{H}_{8}$, as the critical temperature of hydrocarbons in- crease with temperature $\left(\mathrm{C}_{3} \mathrm{H}_{8}: 96.8^{\circ} \mathrm{C}\right.$ and $\mathrm{C}_{4} \mathrm{H}_{10}: 152.0^{\circ} \mathrm{C}$, Konnerup-Madsen 1980 ). That fluorescence of hydrocarbon mixtures is normally caused by the aromatic hydrocarbons, is in good accordance with the observed lack of fluorescence of the lightest hydrocarbon inclusions (lowest $T_{h}$ ), as naturally occuring light hydrocarbon mixtures are practically devoid of aromatic hydrocarbons.

The significance of the fluids

High salinities of porewaters of sediments are often considered to be due to membrane filtration and expulsion of part of the water during compaction of the sediment (Kharaka and Berry 1973), the residual waters being enriched in certain ions. The highly saline fluids found in the majority of inclusions may therefore represent fluids entrapped close to the end of compaction stage. In present day sedimentary basins, without major salt deposits, compaction is completed at 
Table 3. Leco and Rock-eval analyses of Alum shale, Bornholm. See text for further explanation.

\begin{tabular}{lrrrrr}
\hline Sample & \multicolumn{2}{c}{ Leco } & \multicolumn{3}{c}{ Rock eval } \\
no. & TC & TOC & S1* & S2 $^{*}$ & S3* $^{*}$ \\
\hline EFP-4 & $1.52 \%$ & $0.38 \%$ & 0.05 & 0.07 & 0.00 \\
EFP-5 & $3.56 \%$ & $3.19 \%$ & 0.09 & 0.04 & 0.00 \\
EFP-8 & $9.78 \%$ & $0.26 \%$ & 0.00 & 0.00 & 0.08 \\
EFP-31 & $9.14 \%$ & $0.21 \%$ & 0.04 & 0.00 & 0.09 \\
EFP-32 & $8.92 \%$ & $0.14 \%$ & 0.02 & 0.03 & 0.00 \\
EFP-34 & $12.21 \%$ & $7.40 \%$ & 0.05 & 0.06 & 0.33 \\
\hline
\end{tabular}

TC total carbon, TOC total organic carbon * mg/g sediment.

depths of $3-3.5 \mathrm{~km}$, with attained pore water salinities around 25 eq. wt. $\% \mathrm{CaCl}_{2}$. The lower salinities of fluids found in the Cambro-Ordovician shales and limestone sequence might be explained by clay mineral diagenesis or by influx of dilute surface waters. However, influx of surface waters is unlikely, as the low salinities are only present in inclusions with high homogenization temperatures. Alteration of smectites to illite (Burst, 1969; Perry \& Hower, 1972), starting at 90-100 ${ }^{\circ} \mathrm{C}$, will digest $\mathrm{K}^{+}$and yield $\mathrm{Ca}^{++}, \mathrm{Mg}^{++}$, $\mathrm{Fe}^{++}$and $\mathrm{H}_{2} \mathrm{O}$ (Foscolos and Kodama 1974). Alteration of $1 \mathrm{~g}$ of smectite will release $270 \mathrm{mg}$ $\mathrm{H}_{2} \mathrm{O}$ (Foscolos 1984) and lower the salinities of the porewater significantly. Such a process appears to be supported by the mineralogy of the shales, which consists of illite and no smectites (Lindgreen \& Thomsen 1982, G. Karup-Pedersen, pers.com.). Apparently such a dilution of porewater also occurred in the limestones both above and below the shales. The idealized picture with increasing salinity with depth in sedimentary basins might be blurred by large scale convective flow systems of pore waters, such as those around the North Sea salt diapirs (Jensenius 1987). However, in the case of the Paleozoic rocks no salt deposits or remains of such have been described and large scale migration could only have occurred where large faults may have acted as path ways for the ascending fluids.

The hydrocarbons found in the calcite vein in the Komstad limestone may possibly be derived from kerogen of the Alum shale. However, in the quartz overgrowth of the Rispebjerg sandstone the high $T_{h}$ suggests an external source for these fluids, possibly from deeper strata along faults and injected into the coarse-grained and porous sandstone. Such a scenario has been proposed by
Haszeldine et al. (1984) for the Brent sandstone of the North Sea.

\section{Geothermometry and geobarometry}

The homogenization temperature and the salinity of an aqueous inclusion define the density of the entrapped aqueous fluid and the isochoric $(\mathrm{P}, \mathrm{T})$ path along which that particular homogeneous fluid was trapped. For entrapment of a homogeneous fluid the homogenization temperature only represents a minimum temperature. The actual trapping temperature of pressure may be found by plotting an assumed or known geothermal gradient (fig. 11) together with the isochore. In figure 11 isochores corresponding to the two lowest homogenization temperature peaks of figure 8 are shown. Salinities of the lower thermal peak of 25 eq. wt. $\% \mathrm{CaCl}_{2}$ and of 5 eq. wt. $\% \mathrm{CaCl}_{2}$ for the higher thermal peak have been used. The isochore paths are based on data for the $\mathrm{NaCl}-\mathrm{H}_{2} \mathrm{O}$ system (Potter, 1977), because of the lack of $\mathrm{P}, \mathrm{V}, \mathrm{T}$ data for the $\mathrm{CaCl}_{2}-\mathrm{H}_{2} \mathrm{O}$ system. The $\mathrm{NaCl}-\mathrm{H}_{2} \mathrm{O}$ system can be used for low $\mathrm{CaCl}_{2}$ contents (Potter and Clynne, 1978), but for inclusions with very high $\mathrm{CaCl}_{2} / \mathrm{NaCl}+\mathrm{CaCl}_{2}$ ratios the isochores are only tentative.

Also included in figure 11 are various geothermal gradients. Down to a depth of $1 \mathrm{~km}$ in the Danish Central Graben the geothermal gradient varies from $25^{\circ} \mathrm{C} / \mathrm{km}$ in the $S W$ to $40^{\circ} \mathrm{C} / \mathrm{km}$ in the $\mathrm{NE}$ close to the marginal fault; the lower Cretaceous and upper Jurassic have an average geothermal gradient of $42^{\circ} \mathrm{C} / \mathrm{km}$ (Klint-Jensen, 1983). In the case of Slagelse 1 a marked gradient in reflectivity of organic matter (Thomsen, pers. com.) and in acritarch coloration (Kock-Clausen, pers.com.) is present throughout the Silurian and also suggests a high geothermal gradient. Therefore a gradient of $35^{\circ}$ to $45^{\circ} \mathrm{C} / \mathrm{km}$ is considered a reasonable approximation for the Lower Cambrian and Ordovician samples of Bornholm and Slagelse 1 during their burial. Abnormal subsurface fluid pressures are often known to develop in fine-grained rocks such as shales, at depths below $3000 \mathrm{~m}$ (Dickenson, 1953), and to result in fracturing (Gretener, 1976; Watts, 1983). In general the abnormal pressure does not exceed $90 \%$ of lithostatic pressure (Dickenson, 1953, Chapman, 1972). Thus for the $82^{\circ} \mathrm{C}$ peak the correction is carried out under an assumption of hydrostatic pressure and for the $136^{\circ} \mathrm{C}$ peak the correc- 
tion is carried our under an assumption of both hydrostatic and $90 \%$ of lithostatic pressure. In the case of Nøvling 1 and Rønde 1 the intrusion of the Permian sills probably caused a local increase in the temperature and the suggested pressure correction should therefore be used with care.

The intersection of the isochores of the higher temperature peak and the different geothermal gradients vary considerably (fig. 11). If the samples of Bornholm (EFP 1 and 6 excluded) are assumed to represent entrapment at pressures equivalent to $90 \%$ of lithostatic pressure, then general conditions of about $4.5 \mathrm{~km}$ and $220^{\circ} \mathrm{C}$ are indicated.

Rock Eval and Leco analyses carried out on 6 samples from the Alum shale from Bornholm (see table 3) all indicate a very high thermal alteration of the samples. $R_{o}$ of Bornholm Lower Paleozoic samples ranges between 2.25 and 3.04 and the Cambro-Silurian of Slagelse 1 varies from 2.56 at the top of the sequence to 3.33 at the bottom (over a $292 \mathrm{~m}$ interval) (Thomsen pers. com. 1985). Mineralogical investigations (Lindgreen and Thomsen, 1982) suggest that low grade metamorphic conditions were attained for the Cambro-Silurian of both Bornholm and Slagelse 1. Buchardt and Nielsen (1985) suggest, on the basis of stable isotopic work, that temperatures equal to or higher than $90^{\circ} \mathrm{C}$ have been attained in the Cambro-Silurian of Bornholm. Seismic surveys around Bornholm have revealed a Paleozoic sequence up to $4 \mathrm{~km}$ thick (Vejbæk 1985). All the fluid inclusions data except from the quartz veins of Slagelse 1 (EFP-27) and Bornholm (EFP-6) conform to these data though the temperatures are somewhat higher than would be excepted from the $R_{o}$ data (see Waples 1980). This indicates that inclusion entrapment (precipitation of the investigated minerals) happened during a short thermal anomaly, which did not affect the time-temperature dependant maturity indicators such as vitrinite reflectance. This might have occured during a short event of convective flow of porewaters in the basin. The two quartz veins probably represent a relatively early diagenetic event, as their high salinities also indicate. The relatively low temperatures (approx. $100^{\circ} \mathrm{C}$ ) suggested for the calcite vein from Skåne probably represent a diagenetic event much earlier or later than maximum thermal event, as conodont colour alteration indices obtained by Bergstrøm (1980) in the same area indicated a high thermal impact (CAI 4-6), and $R_{o}$ values between 2.00 and 2.50 was obtained by Buchardt et al. (in press) for Skåne. It is not possible to define the formation relative to the main thermal event due to the lack of salinity data.

\section{Regional implications}

Whether the Lower Paleozoic basin was one large or several small basins in crucial to the evaluation of the oil potential of the Lower Paleozoic rocks. In the case of one large basin covering the whole of Denmark, the fluid inclusion data all suggest that the Lower Paleozoic is postmature in respect to oil and gas formation, although the Silurian of Nøvling 1 might be late mature with respect to gas. Towards the south the Paleozoic basin temperature increases as the $\mathrm{Ca}$ ledonian deformation front (Ziegler 1978) is approached. Thus the samples from Åbenrå 1 south of this front give very high temperatures of entrapment.

\section{Conclusions}

1. All the studied samples from the Lower Paleozoic of Denmark are post mature with respect to hydrocarbons, except the Silurian of Nøvling 1 which has a small gas potential.

2. The Lower Paleozoic of Rønde 1, Slagelse 1 and Bornholm has attained temperatures around $200-220^{\circ} \mathrm{C}$. In Åbenrå 1 even higher temperatures have been attained, due to the location south of the Caledonian deformation front.

3. The Silurian of Nøvling 1 and Gotland and the Carboniferous of $\emptyset$ rslev 1 have attained temperatures of $95-110^{\circ} \mathrm{C}$.

4. High salinities (around $25 \mathrm{wt} \%$ salts) are only observed in inclusions trapped at low temperature $\left(100^{\circ} \mathrm{C}\right)$, whereas low salinities (around $5 \mathrm{wt} \%$ salts) are observed in inclusions trapped at high temperatures $\left(210^{\circ} \mathrm{C}\right)$.

5 . The decrease in salinities with increasing temperatures may be explained by dehydration of clay minerals diluting the porewaters. Transformation of smectites to illite starting at 90$100^{\circ} \mathrm{C}$ is a plausible process. 
6. Hydrocarbons inclusions slightly more enriched in heavier hydrocarbons than a typical wet gas are present in calcite veins from the Komstad limestone, Bornholm, and probably originate from the underlying Alum shale, and "prove" that the Alum shale was once a source rock for at least some hydrocarbons.

Acknowledgments. This study is a part of an Energy Research Project, EFP-84 J.no. 2251-401, sponsored by the Danish Ministry of Energy. Project leaders are John Rose-Hansen and Jens Konnerup-Madsen. Thanks are due to the Geological Survey of Denmark, Gunver Karup-Petersen and Arne Thorshøj for supplying samples. Jens Konnerup-Madsen is acknowledged for valuable suggestions regarding the manuscript. John Bailey kindly corrected the English in the manuscript. Lilian Andersen and Gitte Sjørring typed the manuscript.

\section{Dansk sammendrag}

Væske-gas indeslutninger $i$ diagenetisk dannet kvarts og kalkspat er undersøgt med henblik på at bestemme minimums temperaturen samt at få oplysninger om porevandets sammensatning under diagenesen af Paleozoiske sedimenter. Prøver af blotninger fra Bornholm, Skåne og Gotland og af borekerner fra Frederikshavn-1, Rønde-1, Nøvling-1, Åbenrå-1, Slagelse-1 og Ørslev-1 er undersøgt. To hoved typer af fluider er beskrevet: vandige og blandinger af kulbrinter. Baseret på homogeniserings temperaturen kan de vandige indeslutninger groft inddeles i 3 forskellige grupper med aritmetriske gennemsnit på $82^{\circ} \mathrm{C}$ (med saliniteter omkring 25 vægt \% salt ækv.) og $136^{\circ} \mathrm{og}$ $175^{\circ} \mathrm{C}$ (med saliniteter omkring 5 vægt \% salt akv.). Korrelationen mellem temperaturen og saliniteten af indeslutnings vandet forklares med fortynding af saltrigt porevand forårsaget af dehydrering af lermineraler (smectit-illit transformationen). Kulbrinte indeslutningerne, der ofte fluoroscerer grøn-gulligt og homogeniserer $\mathrm{i}$ vaskefasen ved temperaturer mellem $-44^{\circ}$ og $+138^{\circ} \mathrm{C}$. De findes kun i kalkspat gange skærende de Silurer bjergarter fra Nøvling-1 og de Nedre Ordiviciske Komstad kalksten fra Bornholm.

Med hensyn til den termale historie foreslår resultaterne at: 1) modningen af de Kambro-Ordoviciske sedimenter skete før Karbon, 2) alle Kambro-Ordoviciske prøver er overmodne med hensyn til hydrocarbon dannelse, og 3) kun et lille gas potentiel er tilstede i de Øvre Silure til Karbone sedimenter.

\section{References}

Bergstrøm, S. M. 1980: Conodonts as paleotemperature tools in Ordovician rocks of the Caledonides and adjacent areas in Scandinavia and the British Isles. Geol. Foren. Stockholm forh. 120, 377-392.

Bergstrøm, J., Holland, B., Larsson, K., Norling, E. \& Sivhed, U. 1982: Guide to Scania. Sveriges Geol. Unders $\phi k$., ser. $\mathrm{Ca}$, no. $54 ., 95$ p.

Bodnar, R. J. 1983: A method of calculating fluid inclusion volumes based on vapor bubble diameters and P-V-T-X properties of inclusion fluids. Econ. Geol. 78, 535-542.

Buchardt, B. \& Nielsen, A. T. 1985: Stable isotope composition of Lower Paleozoic limestone and antragonite from Bornholm: Evidence for deep burial diagenesis. Bull. Geol. Soc. Denm. 33, 3-4, 415-435.

Buchardt, B., Clausen, J. \& Thomsen, E. (in press): Carbon isotope compositions of Lower Paleozoic Kerogen: Effects of maturation.

Burruss, R. C. 1977: Analyses of fluid inclusions in graphitic metamorphic rocks from Bryant pond, Maine, and Khtada lake, British Columbia: Thermodynamic basis and geological interpretations of observed fluid compositions and molar volumes. Ph.D. dissertation, Princeton University. Princeton, New York. $156 \mathrm{p}$.

Burruss, R. C. 1981: Hydrocarbon fluid inclusions in studies of sedimentary diagenesis. MAC short course in fluid inclusions: Applications to Petrology. Ed. Hollister, L. S. \& Crawford, M. L., 138-156.

Burruss, R. C., Cercone, K. R. \& Harris, P. M. 1983: Fluid inclusion petrography and tectonic-burial history of the Ali No. 2 well: Evidence for timing of diagenesis and oil migration, northern Oman Foredeep. Geology 11, 567-570.

Burruss, R. C., Cercone, K. R. \& Harris, P. M. 1985: Timing of hydrocarbon migration: evidence from fluid inclusions in calcite cements, tectonics and burial history. SEPM special paper no. 36, Carbonate cements, 277-289.

Burst, J. F. 1969: Diagenesis of Gulf Coast clayey sediments and its possible relation to petroleum migration. Bull. Am. Assoc. Pet. Geol. 53,1, 73-93.

Carothers, W. W. \& Kharaka, Y. K. 1980: Stable carbon isotopes of $\mathrm{HCO}_{3-}$ in oilfields waters - implications for the origin of $\mathrm{CO}_{2}$. Geochim. et Cosmochim. Acta 44, 323-332.

Chapman, R. E. 1972: Clays with abnormal interstitial fluid pressure. Bull. Am. Assoc. Pet. Geol. 55,4, 790-795.

Christensen, O. B. 1971: Nedre karbon i dybdeboringen Ørslev 1 på Falster. English summary. Danm. Geol. Survey. Rapport no. 5, $24 \mathrm{p}$.

Crawford, M. L. 1981: Phase equilibria in aqueous fluid inclusions. MAC short course in fluid inclusions: Applications to petrology. Ed. Hollister, L. S. \& Crawford, M. L., Calgary, May 1981, 75-100.

Dickenson, G. 1953: Geological aspects of abnormal reservoir pressures in Gulf Coast, Louisiana. Bull. Am. Assoc. Pet. Geol. 37,2, 410-432.

Fabricius, J. 1984: Formation temperature and chemistry of brine inclusions in euhdral quartz crystals from Permian Salt in the Danish Trough. Bull. mineral. 107, 203-216.

Fabricius, J. 1985: Studies of fluid inclusions in halite and euhedral quartz crystals from salt domes in the NorwegianDanish basin. Sixth Int. Symp. on Salt, Toronto, May 1983. In: B. C. Schreiber \& H. F. Harner (Eds) The Salt Institute Alexandria, Virginia, USA, 1, 247-255.

Foscolos, A. E. 1984: Diagenesis 7. Catagenesis of argillaceous sedimentary rocks. Geoscience Canada, 11,2, 67-75.

Foscolos, A. E. \& Kodama, H. 1974: Diagenesis of clay minerals from Lower Cretaceous shales of northeastern British Columbia. Clay and clay minerals, 22, 319-335.

Gretener, P. E. 1976: Pore pressure: Fundamentals, general ramifications and implications for structural geology. AAGP Continuing education course note series $4.87 \mathrm{p}$.

Hanor, J. S. 1980: Dissolved methane in sedimentary brines: potential effect on the $P, T, V$ properties of fluid inclusions. Econ. Geol. 75, 603-609.

Haszeldine, R. S., Samson, I. M. \& Cornford, C. 1984: Quartz diagenesis and convective fluid movement: Beatrice Oilfield, UK North Sea. Clay Minerals 19, 391-402.

Horsfield, B. \& McLimans, R. K. 1984: Geothermometry and geochemistry of aqueous and oil-bearing fluid inclusions from Fateh Field, Dubai, Ord. Geochem. 6, 733-740.

Jensenius, J. 1987: High temperature diagenesis in a shallow chalk reservoir, the Skjold Oil Field, Danish North Sea: Evidence from fluid inclusions and stable isotopes. $A A P G$ Bull. 71 , no. 11.

Jensenius, J., Buchardt, B., Jørgensen, N. O. and Petersen, S. in prep: $O, C$ and $S r$ isotope studies of the chalk reservoir in 
the Skjold Oil Field, Danish North Sea: Implications for diagenesis.

Jensenius, J., in prep: Fluid inclusion and stable isotope studies of calcite and dolomite associated with seeping asphalt, North Greenland.

Jehl, V. 1975: Le metamorphisme et les fluides associes des roches oceanique de l'Atlantique Nord. These de docteuringenieur, Univ. Nancy I. 242 p.

Kharaka, Y. K. and Berry, F. A. F. 1973: Simultaneous flow of water and solutes through geological membranes-I. Experimental investigation. Geochimica et Cosmochimica Acta $37,2577-2603$.

Konnerup-Madsen, J. 1980: Fluid inclusions in minerals from igneous rocks belonging to the Precambrian continental Gardar rift province: the alkaline llimaussaq intrusion and the alkali acdic igneous complexes. Unpub. Ph.D. Thesis, University of Copenhagen. $140 \mathrm{p}$.

Klint Jensen, P. 1983: Formation temperatures in the Danish Central Graben. Yearbook 1982, Geol. Surv. Denm. 91106.

Leroy, J. 1979: Contribution à l'étalongnage de la pression interne des inclusions fluides lors de leur décrépitation. Bull. Minéralogie, 5-6, 584-593.

Lindgreen, H. \& Thomsen, E. 1982: Investigations on the source rock potential of the Danish onshore area. Danm. Geol. Survey, unpublished report. 91 p.

Linke, W. F., 1958: Solubilities, inorganic and metal-organic compounds. L. D. van Nostrand Co., Princeton New York, $1487 \mathrm{p}$.

Magnusson, N. H., Lundquist, G. \& Regnell, G. 1963: Sveriges geologi. Svenska Bokförlaget/Nordstedts, 698 p.

Morrow, D. W. 1984: Diagenesis 1. Dolomite - Part 1: The chemistry of dolomitisation and dolomite precipitation, Geoscience Canada, 9, no. 1, 5-13.

Odin, G. S. 1982: Numerical dating in stratigraphy. John Wiley \& Sons, Chichester. $1040 \mathrm{p}$.

Pagel, M. 1975: Determination des conditions physiochimiques de silicification diagenetique des gres Athablasca (Canada) au moyen des inclusions fluides. C. R. Acad. Sci. Paris t. 280, Ser. D. pp. 2301-2304.

Perry, E. A. and Hower, J. 1972: Late-stage dehydration in deeply buried pelitic sediments. Bull. Am. Assoc. Pet. Geol. 54, no. 10, 2013-2021.

Potter, R. W. 1977: Pressure corrections for fluid inclusion temperatures based on the volumetric properties of the system NaCl- $\mathrm{H}_{2} \mathrm{O}$. U.S. Geol. Surv. J. Res., 5, 603-607.

Potter, R. W. and Clynne, M. A. 1978: Pressure corrections for fluid inclusion homogenisation temperatures. (Abst.) Int. Assoc. on the Genesis of Ore Deposits, 5 symp., Snowbird Atla. Utah, program and abst.

Poty, B., Leroy, J. and Jachimowicz 1976: A new device for measuring temperatures under the microscope: the Chaixmeca microthermometry apparatus. Bull. soc. Franc. Mineral. Cristal logr. 99, 182-186.

Poulsen, C. 1974: Further contributions to the knowledge of the Paleozoic of Slagelse No. 1, Western Sealand. Danm. Geol. Survey, II rk., no. 101, 42 p.

Rasmussen, L. B., Dinesen, A., Henriksen, S. E., Bang, I., Stenestad, E., Buch, A., Christensen, O. B., Michelsen, O. \& Jacobsen, F. L. 1971: Dybdeboringen Rønde no. 1. in Djursland. Resultaterne af de geologiske undersøgelser. English Summary: The deep test well Rønde no. 1. på Djursland, Denmark. Danm. Geol. Unders., III rk., no. $39,123 \mathrm{p}$.

Rasmussen, L. B., Baartman, J. C., Henriksen, S. E., Kristoffersen, F. N., Dinesen, A., Bang, I., Stenestad, E., Buch, A., Christensen, O. B., Michelsen, O., Hansen, T. J., Jacobsen, F. L. 1973: Dybdeboringen Nøvling 1 i Midtjylland. Resultaterne af de geologiske undersøgelser. English summary: The deep test well Nøvling no. 1 in Central
Jutland, Denmark. The results of the geological investigations. Danm. Geol. Unders., III rk., no. 40,164 p.

Surlyk, F. 1980: Denmark., p. 5-50. In: The Geology of the European countries, Denmark, Finland, Iceland, Norway, Sweden. Dunod.

Svanenberg, H. E. S. 1979: Phase equilibria in carbonic systems and their applications to freezing studies of fluid inclusions. Contrib. Mineral. Petrol. 68, 303-306.

Sønderholm, M. and Fabricius, J. 1983: Fluid inclusions in calcite cement from fractures from the T-1 well. Chalk Project IVf, Open file report, Geol. Survey. Denm., 1983, Copenhagen. $17 \mathrm{p}$.

Thomsen, E., Lindgreen, H. \& Wrang, P. 1983: The source rock potential of Denmark: Geol. Mijnbouw 62, 221-239.

Tiratsoo, N. E. 1973: Oilfields of the world. Scientific Press Ltd. Beaconsfield, England. 375 p.

Touret, J. 1982: An empirical phase diagram for a part of the $\mathrm{N}_{2}-\mathrm{CO}_{2}$ system at low temperature. Chemical Geology, 37, 49-58.

Vejbæk, O. V. 1985: Seismic stratigraphy and tectonics of sedimentary basins around Bornholm, Southern Baltic. Geol. Survey Denm. Serie A, no. 8., 30 p.

Waples, D. W. 1980: Time and temperature in petroleum formation: Application of Lopartin's method to petroleum exploration. Bull. Am. Assoc. Pet. Geol., 64, no. 6, 916926.

Watts, N. L. 1983: Microfractures in chalks of Albuskjell Field, Norwegian sector, North Sea: Possible origin and distribution. Bull. Am. Assoc. Pet. Geol. 62, no. 2, 201-234.

Ziegler, P. A. 1978: North western Europe: Tectonic and basin development. Geol. Mijnbouw. 57, no. 4, 589-626.

\section{Appendix}

Abbreviations:

$A q(1)$ and $\mathrm{Aq}(2)$, aqueous 1- and 2-phase inclusions.

$\mathrm{HC}(1)$ and (2), hydrocarbon 1- and 2-phase inclusions.

$\mathrm{CM}(1), \mathrm{CO}_{2}-\mathrm{CH}_{4} 1$-phase inclusions.

$\mathrm{I}$ isolated, $\mathrm{F}$ fracture bound inclusions.

EFP-1, Rispebjerg sandstone, Bornholm. Well rounded quartz grains with concavo-convex to tangential contacts which are often sutured. In parts the quartz grains are mud supported. Two generations of cement, an early syntaxial quartz overgrowth and a later often with poikilitic calcite which may also cut the detrital quartz grains as thin veins, are present. The sandstone appears to have suffered late tectonic movements. Only fluid inclusions in the quartz cement were studied.

$A q(2): I$ and $F$.

EFP-2+3, Calcite veins from the Komstad limestone, Bornholm. Subhorizontal, only a few $\mathrm{mm}$ wide veins, commonly associated with pyrite. Cathodoluminescence microscopy (CLM) reveals growth zonation in the calcite crystals and shows that they are partly replacive.

$\mathrm{Aq}(2)$ : I and $\mathrm{F}, \mathrm{HC}(1)$ and $\mathrm{HC}(2)$ : I (some have a brownish hue).

EFP-6, Vertical quartz vein cutting Hardeberga sandstone, Bornholm. Consists of up to several $\mathrm{mm}$ large quartz crystals with a blueish hue (amethyst). CLM reveals a thin zone of non-luminescent quartz along the margins of the vein as opposed to the brownish luminescent quartz in the middle. All studied inclusions are located in the middle part of the vein.

$A q(1)$ and $A q(2): F$ (and I).

EFP-7, Black Hardeberga sandstone, Bornholm composed of well rounded quartz grains with sutured to concavo-convex 
contacts. The quartz grains are often overgrown with facetted quartz.

$A q(2): I$ and $F$.

EFP-8, Calcite vein cutting concretion in Cyrtograpyus shale, Bornholm. The vein is $1 \mathrm{~cm}$ wide and CLM shows a zonation of the calcite crystals.

$A q(2): I$.

EFP-9, Calcite from Exulans limestone. The calcite is found in $2 \mathrm{~mm}$ wide veins and under fragments of trilobites. The latter is of early diagenetic origin (precompactional) origin.

$\mathrm{Aq}(2): \mathrm{F}$.

EFP-17, Quartz vein cutting metamorphosed Precambian sandstone, Frederikshavn 1 . The vein is a few $\mathrm{mm}$ wide and parallel to the layering of the mica-rich sandstone.

$A q(2): F$ (two generations of fractures observed).

EFP-19+20, Calcite veins cutting Silurian siltstone, Nøvling 1. Occur as an echelon extensional fissures filled with calcite. CLM reveals that the calcite is altered in a spotted way to dolomite.

$A q(1)$ and $A q(2): F$ (see fig. 3).

EFP-21, Calcite veins cutting Silurian siltstone, Nøvling 1. The veins is small and irregular.

$\mathrm{HC}(2)$ : F (see fig. 3).

EFP-24, Calcite vein cutting Silurian siltstone, Rønde 1. Occuring as numerous veins, of which the majority are $0.5 \mathrm{~mm}$, but a few up to $5 \mathrm{~mm}$, wide. Shear veins interfingering in a sigmoidal pattern. CLM showed a dull yellow-orange calcite with a few markings of brighter calcite.

$\mathrm{Aq}(1)$ and $\mathrm{Aq}(2): \mathrm{F}, \mathrm{CM}(1): \mathrm{I}$.
EFP-27, Vertical $1 \mathrm{~mm}$ wide quartz vein cutting a Silurian siltstone, Slagelse 1.

$A q(2)$ : I and $F$.

EFP-28, Hardeberga sandstone, Slagelse 1. Pure quartz sandstone. The original shapes of the detrital grains are poorly defined because of the lack of a dust rim. Grain contacts are often concavo-convex or sutured and the rock has suffered a slight tectonic brecciation.

Aq(2): I, F.

EFP-31, Calcite veins cutting the Alum shale. Two generations are present: an early one, up to $5 \mathrm{~mm}$ wide, of shear veins and a later, of $1 \mathrm{~mm}$ wide tension veins. In CLM, tension vein calcites are yellow-orange whereas the shear veins are duller yelloworange. All studied inclusions are from the shear veins.

Aq(2): F.

EFP-42, Quartz veins cutting a metamorphosed Ordovician siltstone, Åbenrå 1 . Up to $1 \mathrm{~cm}$ wide and with a great variety of orientations. Fluid inclusions are very abundant.

$A q(2):$ I.

EFP-46, Calcite vein cutting Carboniferous claystone, Ørslev 1. A few $\mathrm{mm}$ wide, vertical and irregular.

$A q(1)$ and $A q(2): I$ and $F$.

EFP-53, Calcite vein cutting the Komstad Limestone, Skåne. Vertical tension vein several $\mathrm{cm}$ wide with up to $2 \mathrm{~cm}$ large calcite crystals.

$A q(1)$ and $A q(2): F$ and $I$.

EFP-54, Mm wide, irregular calcite vein cutting Klinteberg limestone, Gotland.

$A q(2): F$ and $I$. 